\title{
Perbaikan Level Tegangan dan Reduksi Rugi-Rugi Sistem Transmisi Sulbagsel Berbasis Ant Colony Optimization
}

\author{
Ikhlas Kitta ${ }^{1, a}$ \\ ${ }^{1}$ Program Studi Teknik Elektro, Universitas Hasanuddin, Gowa, Indonesia \\ a ikhlaskitta@gmail.com
}

\begin{abstract}
The Ant Colony Optimization (ACO) method is used to determine the location and optimal amount of bank capacitors in the South Sulawesi electric power system (Sulbagsel). The purpose of employing ACO is to determine the ability of ACO as one method for optimization to improve voltage levels and reduce power losses in the electric power system. There are 5 scenarios carried out in this study, scenario 4 and scenario 5 are scenarios for applying the ACO method, the results of these two scenarios are the increase in voltage on the bus and the reduction of power losses in the Sulbagsel system.
\end{abstract}

Keywords—ant colony optimizatio; sulbagsel system; bank capacitors; bus voltage; power losses.

\begin{abstract}
Abstrak-Metode Ant Colony Optimization (ACO) dipakai pada penentuan lokasi dan besaran optimal kapasitor bank pada sisem tenaga listrik Sulawesi Bagian Selatan (Sulbagsel). Maksud dari pemakaian tersebut adalah untuk mengetahui kemampuan ACO sebagai salah satu solusi metode optimalisasi pada perbaikan level tegangan dan mereduksi rugi-rugi daya pada sistem tenaga listrik. Terdapat 5 skenario yang dilakukan pada peneltian ini, skenario 4 dan skenario 5 adalah skenario penerapan metode ACO, hasil dari 2 skenario tersebut adalah peningkatan tegangan pada bus dan pengurangan rugi-rugi daya pada sistem Sulbagsel.
\end{abstract}

Kata Kunci-ant colony optimization; sistem sulbagsel; kapasitor bank; tegangan bus; rugi-rugi daya.

\section{Pendahuluan}

Sistem transmisi tenaga listrik adalah struktur penting dalam sistem tenaga listrik, dan oleh karena itu peningkatan kinerja jaringan transmisi merupakan suatu hal sebagai target utama perusahaan listrik, apalagi jika diterapkan liberalisasi pasar listrik [1]. Suatu sistem tenaga listrik dikatakan memiliki tingkat keandalan yang tinggi apabila sistem tersebut mampu menyediakan pasokan energi listrik yang dibutuhkan oleh konsumen secara kontinyu.

Ada beberapa persoalan yang dihadapi oleh suatu sistem tenaga listrik untuk dapat mensuplai energi listrik secara kontinyu. Salah satunya adalah yang terkait dengan masalah kualitas daya listrik. Karena pusat beban pada umumnya terdapat pada lokasi yang jauh dari pusat pembangkitan tenaga listrik maka dibutuhkan penyaluran daya listrik untuk sampai ke konsumen. Dimana kualitas tegangan sistem diusahakan tetap berada pada level yang telah ditentukan, untuk menjaga keandalan dari aliran daya tetap stabil dan dapat bekerja dengan baik.

Untuk mencapai keinginan tersebut, proses perbaikan tegangan pada jaringan dapat dilakukan dengan menggunakan metode pengaturan tegangan yaitu dengan menggunakan kapasitor bank dan tap transformator [2]. Penempatan secara optimal kapasitor bank pada sistem jaringan transmisi adalah merupakan salah satu solusi yang terbaik, karena hal tersebut akan memiliki efek positif, seperti: peningkatan level tegangan, peningkatan faktor daya, meningkatkan daya maksimum yang dapat ditransmisikan dalam penghantar dan transformator, dan pengurangan rugi-rugi daya aktif dalam sistem tenaga listrik. Semua efek tersebutakan berdampak pada pengurangan biaya operasi untuk perusahaan listrik. Oleh karena itu, untuk mendapatkan manfaat sebesar-besarnya dari penempatan kapasitor bank, maka kapasitor tersebut harus diposisikan dan diukur besaran kapasitasnya menggunakan model dan metode matematika yang sesuai. 
Dalam tulisan ini, perbaikan profil tegangan dan pengurangan rugi-rugi jaringan transmisi dipecahkan dengan penempatan kapasitor bank yang optimal pada sistem tenaga listrik yang diselesaikan dengan menggunakan metode Ant Colony Optimization (ACO).ACOdapat memecahkan masalah optimasi kombinasional yang sulit seperti yang telah diteliti oleh A.Fathurrahman dkk [3] pada optimalisasi aliran daya. Aplikasi ACO pada jaringan distribusi juga sudah diteliti oleh dana D. Yabuarta dkk [4], dimana penggunaan metode ACO untuk rekonfigurasi jaringanmendapatkan hasil sesuai yang diharapkan, karena mampumereduksi rugi-rugi daya. Serta penelitian yang dilaksanakan oleh F. Hia dkk [5] tentang optimasi kapasitas pembangkit di sistem distribusi yang menggunakan ACOdengan parameter fungsi objektif berupa miminimalisasi rugi daya aktif dan perbaikan profil tegangan pada tiap bus.

\section{Metode Penelitian}

\section{A. Data Penelitian}

Data yang digunakan dalam penelitian ini adalah data sistem interkoneksi Sulawesi Selatan, Sulawesi Barat dan Sulawesi Tenggara yang dinamakan Sulawesi Bagian Selatan (Sulbagsel). Data tersebut meliputi tata letak sistem Sulbagsel, yang digambarkan dalam diagram satu garisyang terlihat pada Gambar1, meliputi kapasitas pembangkit, transformator dan saluran transmisi, serta tegangan kerjanya. Dilengkapi dengan data pembebanan sistem serta pola pengoperasian sistem yang ada saat ini.

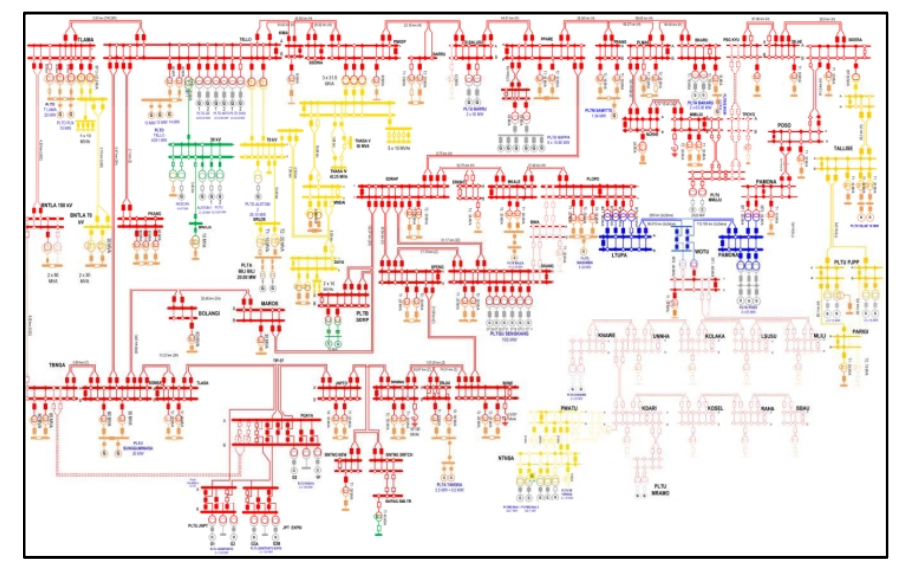

Gambar 1. Diagram satu garis sistem Sulbagsel
Sistem kelistrikan Sulawesi Bagian Selatan (Sulbagsel) saat ini terdiri dari sistem interkoneksi $70 \mathrm{kV}$ dan $150 \mathrm{kV}$ yang dimodelkan dalam 44 bus, dimana busbar tersebut adalah: 1) Gi Bakaru, 2) GI Polmas, 3) GI Majene, 4) GI Mamuju, 5) GI Pinrang, 6) GI Parepare, 7) GI Suppa, 8) GI Sidrap, 9) GI Pltu Barru, 10) GI Barru, 11) GI Pangkep 150kV, 12) GI Pangkep 70kV, 13) GI Tonasa, 14) GI Bosowa, 15) GI Kima, 16) GI Tello 150kV, 17) GI Panakukang, 18) GI Tello 70kV, 19) GI Borongloe, 20) GI Mandai, 21) GI Daya, 22) GI Tello 30kV, 23) GI Barawaja, 24) GI Tallo lama 150 $\mathrm{kV}, 25)$ GI Tallo lama 70kV, 26) GI Bontoala, 27) GI Sungguminasa, 28) GI Tanjung bunga, 29) GI Tallasa, 30) GI Maros, 31) GI Punagaya, 32) GI Jeneponto, 33) Gi Bulukumba, 34) GI Sinjai, 35) GI Bone, 36) GI Soppeng, 37) GI Sengkang, 38) GI Makale, 39) GI Palopo, 40) GI Latuppa, 41) GI Plta Poso, 42) GI Pamona $275 \mathrm{kV}$, 43) GI Pamona $150 \mathrm{kV}$, dan 44) GI Poso.

\section{B. Model Analisis}

Pengolahan data dilakukan dengan software simulasi yang direkayasa berbasis ACO. Ada beberapa tahap yang dilalui dalam pengolahan data yang dibuat dalam 3 skenario perhitungan. Adapun skenario tersebut adalah :

1) Skenario 1, yaitu skenario dasar atau eksisting, dimana sistem dikondisikan pada kondisi tanpa penambahan apapun. Kondisi dasar ini akan dipakai sebagai dasar untuk membandingkan dengan hasil dari skenario 2, skenario 3 , skenario 4 dan skenario 5 , dimana skenario tersebut merupakan scenario penambahan kapasitor bank pada sistem Sulbasel.

2) Skenario 2, yaitu penambahan kapasitor bank pada semua bus di sistem Sulbagsel yang analisis menggunakan Newton Rhapson.

3) Skenario 3, yaitu penambahan kapasitor bank pada bus kritis di bawah $0.955 \mathrm{pu}$, dan analisis menggunakan Newton Rhapson.

4) Skenario 4, yaitu penambahan kapasitor bank pada semua bus di sistem Sulbagsel yang dianalisis menggunakan Newton Rhapson dan ACO. 
5) Skenario 5, yaitu penambahan kapasitor bank pada bus kritis di bawah 0.955 pu ysng dianalisis menggunakan Newton Rhapson dan ACO.

Berdasarkan data-data sistem tersebut, dilakukan perhitungan aliran daya pada kondisi normal atau kondisi sebelum dilakukan penambahan kapasitor. Pemasangan kapasitor secara paralel diharapkan akan dapat menurunkan rugi-rugi daya serta peningkatan kualitas tegangan. Dari perolehan tersebut akan terlihat bagaimana profil tegangan busbar pada interkoneksi sistem sekaligus berapa rugi-rugi daya yang ditimbulkan oleh jaringan transmisi sistem Sulbagsel tersebut. Ukuran kapasitor bank maksimal yang digunakan pada penelitian ini dibatasi maksimum 10 MVAr untuk setiap bus. Hal ini dilakukan karena ukuran tersebut dapat mempengaruhi besar profil tegangan agar sesuai dengan standar yang telah diizinkan.

Dalam penyelesaian masalah aliran daya, sistem tenaga diasumsikan beroperasi pada keadaan seimbang dan digunakan model satu fase. Untuk menghitung aliran daya pada jaringan sederhana dengan bentuk radial dapat dilakukan secara analitik, tetapi untuk jaringan yang lebih rumit diselesaikan secara iterasi. Ada empat kuantitas berupa parameter listrik yang berhubungan dengan setiap bus, yaitu magnitude tegangan $|V|$, sudut fase tegangan $\theta$, daya aktif $P$, dan daya reaktif $Q$.

Metode aliran daya yang digunakan dalam penelitian ini adalah metoda Newton Raphson [6,7,8]. Dasar dari metode tersebut dalam penyelesaian aliran daya adalah deret Taylor untuk suatu fungsi dengan dua variable lebih. Metode Newton Rhapson menyelesaikan masalah aliran daya dengan menggunakan suatu set persamaan non linier untuk menghitung besarnya tegangan dan sudut fasa tegangan tiap bus. Persamaan tersebut diperlihatkan pada persamaan (1). Data yang dibutuhkan untuk menghitung aliran daya dengan metode NewtonRaphson adalah tegangan yang terjadi pada saluran, sudut tegangan, resistansi, reaktansi, tipe bus, besarnya daya pembangkitan, dan besarnya beban yang terjadi.

$$
P_{i}-j Q_{i}=\left|V_{i}\right| \angle-\theta_{i} \cdot \sum_{j=1}^{n}\left|Y_{i}\right|\left|V_{j}\right| \angle \alpha_{i}+\theta_{j}
$$

dimana $P$ sebagai daya aktif, $Q$ sebagai daya reaktif, $V$ sebagai tegangan bus, dan $Y$ sebagai admitansi.
Langkah-langkah solusi aliran daya dengan metode Newton-Raphson adalah sebagai berikut:

1) Pemodelan sistem tenaga listrik Sulbagsel. Kemudian dilanjutkan kegiatan pengumpulkan data pada gardu induk yang terdapat pada sistem Sulbagsel untuk menganalisis aliran daya.

2) Membuat matriks admitansi bus untuk sistem Sulbagsel.

3) Perhitungan daya aktif dan daya reaktif, jika sudah sesuai dengan data maka proses perhitungan selesai, jika tidak sesuai maka dilanjutkan dengan proses perhitungan elemen-elemen matrik Jacobian untuk mengoreksi besar nilai tegangan dan selanjutnya melakukan perhitungan dengan tegangan bus yang baru tersebut.

4) Perhitungan pada iterasi selanjutnya dengan menghitung ulang besar daya aktif dan daya reaktif hingga mendapat data aliran daya yang sesuai.

Optimalisasi besaran daya reaktif dan letak kapasitor bank yang dibutuhkan pada sistem Sulbagsel menggunakan metode ACO. ACO merupakan metode yang termasuk dalam kelompok swarm intelligence dimana inspirasi yang digunakan dalam penyelesaian masalah berasal dari perilaku kumpulan atau kawanan semut yang diperkenalkan oleh Dorigo dkk [9].

Koloni semut dapat menemukan jalur terpendek antara sarang dan sumber makanan berdasarkan jejak kaki pada lintasan yang telah dilewati. Semakin banyak semut yang melewati suatu lintasan maka semakin jelas bekas jejak kakinya. Serta semut akan meninggalkan pheromone ditiap lintasan yang dilaluinya dan mempengaruhi kemungkinan pemilihan lintasan oleh semut-semut yang mengikuti dibelakangnya. Hal ini menyebabkan lintasan yang dilalui semut dalam jumlah sedikit semakin lama semakin berkurang kepadatan semut yang melewatinya, atau bahkan akan tidak dilewati sama sekali. Lintasan tersebut sangat dipengearuhi oleh sifat pheromone yang dapat menguap. Sebaliknya lintasan yang dilalui semut dalam jumlah banyak semakin lama akan semakin bertambah kepadatan semut yang melewatinya atau bahkan semua semut melewati lintasan tersebut. 
Persamaan dasar untuk menentukan tempat tujuan, dalam hal ini tempat tujuan adalah node atau bus dalam sistem Sulbagsel, digunakan persamaan probabilitas sebagaimana ditampilkan pada persamaan (2) [10].

$P_{i}^{k}=\frac{\left[\tau_{i}\right]^{\alpha}\left[\eta_{i}\right]^{\beta}}{\sum\left[\tau_{i k^{\prime}}\right]^{\alpha}\left[\eta_{i k^{\prime}}\right]^{\beta}}$

dimana $i$ sebagai indeks tempat asal, $j$ sebagai indeks tempat tujuan, $\eta_{i j}$ sebagai visibilitas antar tempat, dan $\tau_{i j}$ sebagai intensitas jejak semut.

Berikut ditampilkan algoritma penyelesaian dengan ACO [11], [12]:

1) Membentuk intensitas jejak semut antar tempat dan perubahannya, dimana $i j$ harus diinisialisasikan sebelum memulai siklus.

2) Menetapkan siklus semut dengan cara menginisialisasi awal kandidat rute yang diprakirakan akan ditempuh oleh semut. Kemudian membuat grafik ACO sebagai jalur perjalanan semut dengan merepresentasikan kondisi sistem Sulbagsel.

3) Menetapkan jumlah semut dan jumlah node yang akan dilewati yang dipresentasikan dalam bentuk pembuatan tabu list jalur perjalanan semut sehingga masing-masing semut dapat membuat jalur perjalanan lengkap dan dapat mengetahui panjang jalur perjalanan masing-masing semut.

4) Menetapkan pengendali intensitas jejak semut danvisibilitas antara tempat $\eta_{i j}$, dimana $\alpha$ digunakan dalam persamaan probabilitas node yang akan dikunjungi, serta $\eta_{i j}$ digunakan dalam persamaan probabilitas tempat yang akan dikunjungi.

5) Tetapan pengendali visibilitas $\beta$, dimana $\beta$ digunakan dalam persamaan probabilitas bus (GI) yang akan dikunjungi dan berfungsi sebagai pengendali visibilitas.

6) Memodifikasi nilai pheromone dengan tujuan mempengaruhi semut pada iterasi selanjutnya agar membentuk solusi yang lebih baik pada semut yang sebelumnya dengan pembaruan pheromone lokal dan pembaruan pheromone global.
7) Uji konvergensi, dimana pada ACO konvergensi diartikanjika semua semut mengambil lintasan terbaik yangsama. Jika belum konvergensi, koloni semut akankembali kesarang dan memulai pencarian makananlagi. Jika iterasi sudah mencapai maksimum, didapatkan hasil terbaik nilai dan tabu perjalanannya untuk menentukan letak dan kapasitas dari kapasitor bank.

Pada simulasi ini, ACO dipakai untuk mengoptimisasi aliran daya dengan menginjeksi semua bus yang profil tegangannya di bawah standar dengan kapasitor bank. ACO dipakai untuk mengoptimisasi aliran daya dengan menggunakan parameter-parameter, yaitu: a) Jumlah semut $=50$, b) Nilai $\alpha=0.9$, c) Nilai Q $=100$, dan d) Iterasi maksimum $=150$.

\section{Hasil dan Pembahasan}

Kondisi sistem kelistrikan Sulbagsel yang dimodelkan pada skenario 1, dianalisis menggunakan metode Newton Raphson berdasarkan data pembangkitan, data pembebanan, dan data transmisi sistem Sulbagsel yang ditunjukkan pada Tabel 1.

Dari Tabel 1 diperlihatkan profil tegangan skenario 1 yang juga merupakan kondisi sistem Sulbagsel tanpa adanya injeksi daya reaktif dari kapasitor bank. Hasil dari studi aliran daya diperoleh profil tegangan setiap bus berkisar antara $0.95 \mathrm{pu}$ sampai dengan $1.03 \mathrm{pu}$. Tegangan kerja ini masih berada dalam batas-batas yang sesuai SNI dan IEEE Standar, yaitu batas atas dan batas bawah perubahan tegangan antara $-5 \%$ dan $+5 \%$ dari tegangan nominal (1.0 pu). Bus nomor 26 yaitu bus GI Bontoala yang berada di Kota Makassar yang memiliki tegangan yang paling rendah dibandingkan dengan busbus lainnya, yakni sebesar $0.95 \mathrm{pu}$.

\section{A. Profil Tegangan Bus}

.Dari hasil analisis aliran daya pada Tabel 1 tersebut terlihat jelas bahwa tidak semua bus memiliki nilai profil tegangan yang aman yaitu 0.955 pu. Pada Tabel 1 diperoleh bus-bus yang profil tegangannya dibawah 0.955 pu. Bus-bus tersebut adalah bus 13 dan 26. Kedua bas ini merupakan bus kandidat yang akandiinjeksi oleh daya reaktif kapasitor bank. 
Tabel 1. Hasil simulasi aliran daya untuk skenario 1

\begin{tabular}{|c|c|c|c|c|c|c||}
\hline \multirow{2}{*}{$\begin{array}{c}\text { No. } \\
\text { Bus }\end{array}$} & Tegangan & \multicolumn{2}{|c|}{ Beban } & \multicolumn{2}{|c|}{ Generator } & Kapasitor \\
\cline { 3 - 7 } & MW & MVAr & MW & MVAr & MVAr \\
\hline 1 & 1.030 & 3.5 & 0.2 & -13.0 & 168.4 & 0.0 \\
\hline 2 & 1.005 & 22.0 & 4.1 & 0.0 & 0.0 & 0.0 \\
\hline 3 & 1.001 & 23.3 & 3.7 & 0.0 & 0.0 & 0.0 \\
\hline 4 & 0.998 & 9.6 & 4.8 & 0.0 & 0.0 & 0.0 \\
\hline 5 & 1.000 & 24.4 & 6.2 & 14.3 & -118.6 & 0.0 \\
\hline 6 & 1.002 & 18.7 & 4.7 & 0.0 & 0.0 & 0.0 \\
\hline 7 & 1.000 & 0.0 & 0.0 & 31.1 & -15.1 & 0.0 \\
\hline 8 & 0.999 & 26.5 & 10.3 & 0.0 & 0.0 & 0.0 \\
\hline 9 & 1.000 & 0.0 & 0.0 & 60.4 & 38.7 & 0.0 \\
\hline 10 & 0.973 & 10.1 & 2.4 & 0.0 & 0.0 & 0.0 \\
\hline 11 & 0.966 & 22.1 & 8.0 & 0.0 & 0.0 & 0.0 \\
\hline 12 & 0.966 & 0.0 & 0.0 & 0.0 & 0.0 & 0.0 \\
\hline 13 & 0.952 & 18.9 & 10.6 & 0.0 & 0.0 & 0.0 \\
\hline 14 & 0.963 & 33.1 & 15.4 & 0.0 & 0.0 & 0.0 \\
\hline 15 & 0.960 & 18.0 & 5.8 & 0.0 & 0.0 & 0.0 \\
\hline 16 & 0.970 & 63.3 & 18.3 & 21.0 & 32.3 & 0.0 \\
\hline 17 & 0.960 & 68.3 & 17.7 & 0.0 & 0.0 & 0.0 \\
\hline 18 & 0.968 & 0.0 & -20.0 & 0.0 & 0.0 & 0.0 \\
\hline 19 & 0.960 & 11.4 & 0.0 & 5.2 & -12.7 & 0.0 \\
\hline 20 & 0.961 & 24.3 & 2.6 & 0.0 & 0.0 & 0.0 \\
\hline 21 & 0.961 & 45.5 & 2.8 & 0.0 & 0.0 & 0.0 \\
\hline 22 & 0.970 & 0.0 & 0.0 & 0.0 & 0.0 & 0.0 \\
\hline 23 & 0.971 & 0.0 & 0.0 & 0.0 & 0.0 & 0.0 \\
\hline 24 & 0.970 & 19.7 & 4.7 & 12.6 & 15.5 & 0.0 \\
\hline 25 & 0.959 & 0.0 & 0.0 & 0.0 & 0.0 & 0.0 \\
\hline 26 & 0.950 & 26.5 & 7.7 & 0.0 & 0.0 & 0.0 \\
\hline 27 & 0.980 & 15.7 & 3.6 & 20.0 & 82.8 & 0.0 \\
\hline 28 & 0.965 & 55.2 & 16.7 & 0.0 & 0.0 & 0.0 \\
\hline 29 & 0.990 & 20.6 & 4.7 & 79.0 & -15.5 & 0.0 \\
\hline 30 & 0.986 & 18.6 & 5.5 & 0.0 & 0.0 & 0.0 \\
\hline 31 & 1.000 & 0.0 & 0.0 & 196.1 & 2.7 & 0.0 \\
\hline 32 & 0.990 & 17.4 & 3.4 & 0.0 & 0.0 & 0.0 \\
\hline 33 & 0.995 & 27.1 & 6.5 & 0.0 & 0.0 & 0.0 \\
\hline 34 & 1.000 & 21.9 & 4.6 & 4.0 & 40.7 & 0.0 \\
\hline 35 & 0.999 & 32.1 & 8.2 & 0.0 & 0.0 & 0.0 \\
\hline 36 & 1.000 & 14.1 & 3.4 & 0.0 & 0.0 & 0.0 \\
\hline 37 & 1.020 & 28.4 & 11.5 & 265.2 & -2.4 & 0.0 \\
\hline 38 & 1.020 & 11.9 & 1.5 & 8.2 & 107.1 & 0.0 \\
\hline 39 & 1.000 & 49.2 & 0.0 & 4.0 & 59.2 & 0.0 \\
\hline 40 & 1.027 & 0.0 & 0.0 & 0.0 & 0.0 & 0.0 \\
\hline 41 & 1.000 & 0.0 & 0.0 & 195.0 & -5.2 & 0.0 \\
\hline 42 & 1.000 & 0.0 & 0.0 & 0.0 & 0.0 & 0.0 \\
\hline 43 & 0.999 & 4.9 & 0.5 & 0.0 & 0.0 & 0.0 \\
\hline 44 & 0.998 & 11.0 & 1.8 & 0.0 & 0.0 & 0.0 \\
\hline & & & & & & \\
\hline
\end{tabular}

Pada skenario 2 tegangan pada semua bus mengalami perbaikan. Hal ini merupakan hasil dari injeksi daya reaktif pada setiap bus di sistem Sulbagsel. Skenario 2 simulasi dilakukan dengan memasang kapasitor banksebesar 10 MVAr pada masing-masing bus di sistem Sulbagsel. Skenario 2 ini mengubah tegangan di bus 26 dari 0.950 pu menjadi 0.968 pu. Begitupula pada bus 13 yaitu dari 0.952 pu menjadi $0.982 \mathrm{pu}$.
Selanjutnya sistem Sulbagsel diterapkan metode ACO untuk mendapatkan optimisasi besaran daya reaktif pada setiap bus. Pada skenario 4, simulasi dilakukan dengan menganggap setiap bus adalah kandidat tempat pemasangan kapasitor bank. Skenario 2 ini mendapatkan perubahan profil tegangan di bus 26 dari $0.950 \mathrm{pu}$ menjadi 0.956 pu. Begitupula pada bus 13 yaitu dari 0.952 pu menjadi $0.973 \mathrm{pu}$.

Perbandingan profil tegangan antara skenario 1, skenario 2 dan skenario 4 direpresentasikan pada Gambar 2.

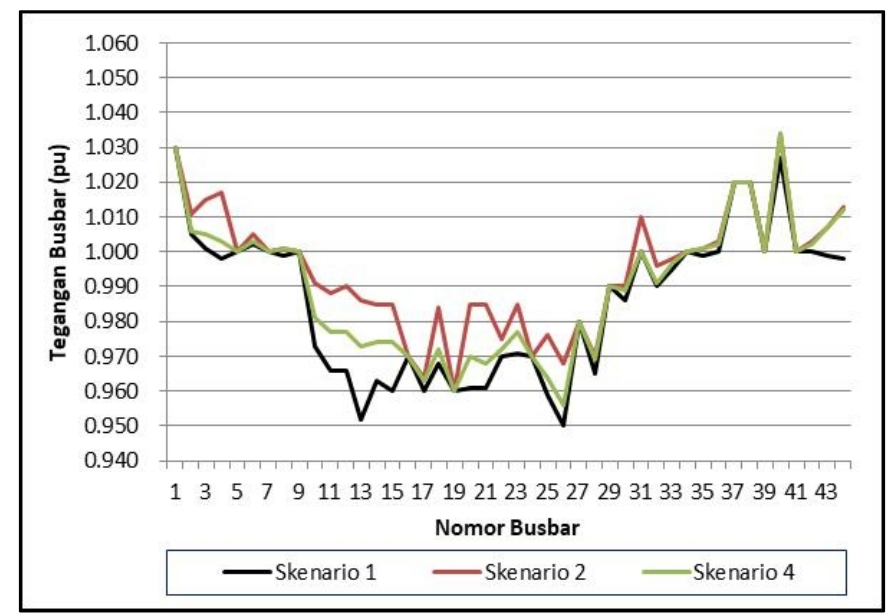

Gambar 2. Profil tegangan sistem Sulbagsel berdasarkan skenario 1, skenario 2 dan skenario 4

Sedangkan untuk skenario 3 dan skenario 5 simulasi dilakukan dengan memasang kapasitor bank pada busbus yang memiliki profil tegangan paling rendah, yaitu bus 13 dan bus 26 bus. Bus-bus ini merupakan bus kandidat yang akan diinjeksi oleh daya reaktif dari kapasitor bank.

Skenario 3 merupakan scenario simulasi perbaikan profil tegangan dengan cara menginjeksi daya reaktif, dimana kapasitor bank ditempatkan pada bus 13 dan bus 26. Nilai kapasitor bank tersebut masing-masing sebesar 10 MVAr.Hasil dari simulasi ini adalah mendapatkan profil tegangan semua bus yang lebih baik dari profil tegangan bus pada skenario 1 . Skenario 3 ini mengubah tegangan di bus 13 dari $0.952 \mathrm{pu}$ menjadi $0.965 \mathrm{pu}$. Begitupula pada bus 26 yaitu dari 0.950 pu menjadi $0.960 \mathrm{pu}$.

Berdasarkan hasil analisis aliran daya dan optimalisasi daya reaktif menggunakan metode Newton 
Raphson dan metode ACO pada skenario 5, maka tegangan pada bus 13 berubah dari 0.952 pu menjadi $0.966 \mathrm{pu}$, sedangkan tegangan pada bus 26 berubah dari 0.95 pu menjadi 0.957 pu. Hal tersebut diperlihatkan pada Gambar 3.

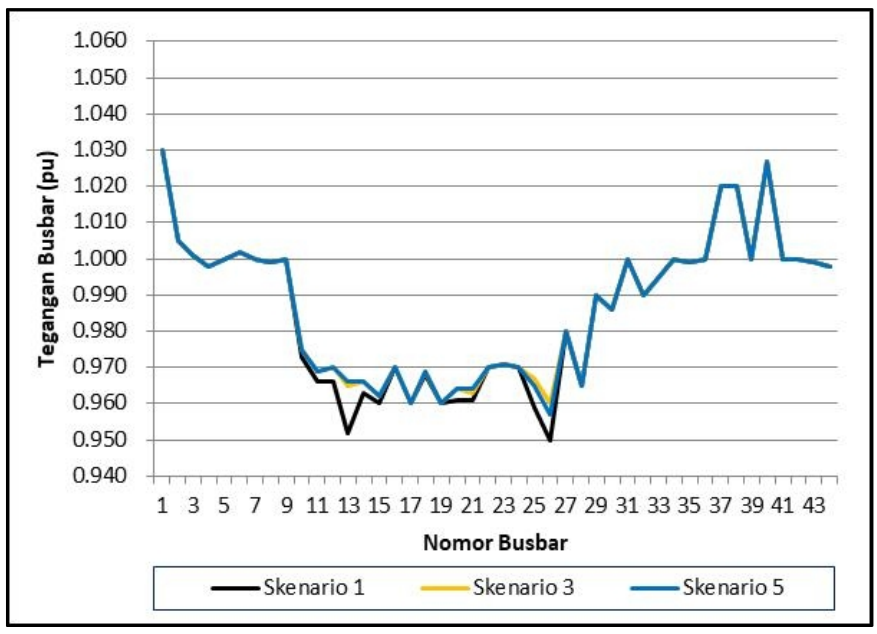

Gambar 3. Profil tegangan sistem Sulbagsel berdasarkan skenario 1 , scenario 3 dan skenario 5

\section{B. Rugi-Rugi Daya Sistem}

Aliran daya setiap saat pada sistem selalu berubah, hal ini disebabkan karena perubahan beban yang setiap saat terjadi. Dari Tabel 1 dan Tabel 2 dapat dilihat bahwa kondisi awal, yaitu kondisi skenario 1 dimana sistem tanpa pemasangan kapasitor bank yang menginjeksikan daya reaktif pada sistem Sulbagsel memiliki kondisi beban sebesar 817.3 MW dan 181.9 MVAr, kondisi daya pembangkit 903.1 MW dan 377.7 MVAr. Rugi-rugi daya pada sistem Sulbagsel sebesar 85.8 MW dan 195.9 MVAr.

Tabel 2. Kondisi sistem Sulsel berdasarkan scenario 1, 2 dan 3

\begin{tabular}{|l|l|r|r|r|r|r||}
\hline \multicolumn{2}{|c|}{} & Skenario 1 & Skenario 2 & Skenario 3 & Skenario 4 & Skenario 5 \\
\hline \multirow{2}{*}{ Generator } & MW & 903.1 & 902.7 & 903.0 & 902.3 & 903.0 \\
\cline { 2 - 7 } & MVAr & 377.7 & $(64.1)$ & 357.2 & 154.5 & 359.7 \\
\hline \multirow{2}{*}{ Beban } & MW & 817.3 & 817.3 & 817.3 & 817.3 & 817.3 \\
\cline { 2 - 7 } & MVAr & 181.9 & 181.9 & 181.9 & 181.9 & 181.9 \\
\hline \multirow{2}{*}{ Kapasitor } & MVAr & - & 440.0 & 20.0 & 221.0 & 17.5 \\
\hline \multirow{2}{*}{ Losses } & MW & 85.79 & 85.38 & 85.68 & 85.04 & 85.67 \\
\cline { 2 - 7 } & MVAr & 195.9 & 194.0 & 195.3 & 193.6 & 195.3 \\
\hline
\end{tabular}

Pada Tabel 2 dijelaskan tentang besarnya rugi-rugi daya pada sistem setelah dipasang bank kapasitor pada skenario 4 adalah sebesar 85.0 MW dan 193.6 MVAr, atau mengalami penurunan daya sebesar $0.8 \mathrm{MW}$ dan
0.3 MVAr. Penurunan rugi-rugi daya tersebut dikarenakan adanya injeksi daya reaktif pada sistem Sulbagsel sebesar 221 MVAr. Lokasi dan besar daya reaktif kapasitor bank tersebut adalah Bus 1 sebesar 5.5 MVAr, Bus 2 sebesar 2.5 MVAr, Bus 3 sebesar 2.5 MVAr, Bus 4 sebesar 2.0 MVAr, bus 5 sebesar 5.0 MVAr, bus 6 sebesar 1.5 MVAr, bus 7 sebesar 5.5 MVAr, bus 8 sebesar 8.0 MVAr, bus 9 sebesar 1.5 MVAr, bus 10 sebesar 2.5 MVAr, bus 11 sebesar 4.0 MVAr, bus 12 sebesar 4.5 MVAr, bus 13 sebesar 10.0 MVAr, bus 14 sebesar 9.5 MVAr, bus 15 sebesar 6.5 MVAr, bus 16 sebesar 0.0, bus 17 sebesar 8.0 MVAr, bus 18 sebesar $0.0 \mathrm{MVAr}$, bus 19 sebesar 4.0 MVAr, bus 20 sebesar $0.5 \mathrm{MVAr}$, bus 21 sebesar $0.5 \mathrm{MVAr}$, bus 22 sebesar 1.5 MVAr, bus 23 sebesar 5.0 MVAr, bus 24 sebesar 3.0 MVAr, bus 25 sebesar 2.0 MVAr, bus 26 sebesar 4.0 MVAr, bus 27 sebesar 5.0 MVAr, bus 28 sebesar 9.5 MVAr, bus 29 sebesar 8.5 MVAr, bus 30 sebesar 9.5 MVAr, bus 31 sebesar 8.0 MVAr, bus 32 sebesar 4.0 MVAr, bus 33 sebesar 7.5 MVAr, bus 34 sebesar 2.0 MVAr, bus 35 sebesar 9.5 MVAr, bus 36 sebesar 7.0 MVAr, bus 37 sebesar 9.0 MVAr, bus 38 sebesar 1.0 MVAr, bus 39 sebesar 1.5 MVAr, bus 40 sebesar 10.0 MVAr, bus 41 sebesar 3.5 MVAr, bus 42 sebesar 7.0 MVAr, bus 43 sebesar 10.0 MVAr, bus 44 sebesar 9.0 MVAr.

Untuk skenario 5 yang memasang kapasitor bank pada bus 13 dan bus 26 dengan kapasitas sebesar 10.5 MVAr dan 7 MVAr. Hasil dari optimalisasi ini adalah didapatkan total daya pembangkitan sebesar 903.5 MW dan 359.7 MVAr, serta rugi-rugi daya yang didapat sebesar 85.7 MW dan 195.3 MVAr.

Berdasarkan penjelasan di atas maka dilihat dari ukuran kapasitor bank yang digunakan dapat disimpulkan bahwa menggunakan metode ACO dapat membuat ukuran kapasitor bank yang dipasang pada bus kritis sesuai dengan kebutuhan untuk mengubah profil tegangan dan mengurangi rugi-rugi daya. Aplikasi ACO pada skenario 5 lebih optimal dengan injeksi daya reaktif yang lebih sedikit dibandingkan dengan skenario 2, skenario 3 dan skenario 4. Skenario 5 menginjeksi daya reaktif dari kapasitor bank sebesar 17.5 MVAr, sedangkan skenario 2 sebesar $440 \mathrm{MVAr}$, skenario 3 sebesar 20 MVAr, dan skenario 4 sebesar 221 MVAr. 
Sehingga penentuan awal lokasi bus yang akan dijadikan kandidat akan mengoptimalkan pemakaian ACO pada perbaikan sistem tenaga Sulbagsel.

\section{Kesimpulan}

Kesimpulan dari penelitian ini adalah:

1. Injeksi daya reaktif dari kapasitor bank dapat memperbaki tegangan dan pengurangan rugirugi daya sistem tenaga listrik, hal ini dibuktikan dengan simulasi yang diterapkan pada sistem Sulawesi Bagian Selatan (Sulbagsel), dimana skenario 2 dan skenario 3 menghasilkan profil tegangan pada semua bus dan rugi-rugi daya pada jaringan lebih baik dibandingkan pada skenario 1.

2. Metode Ant Colony Optimization (ACO) memberikan hasil lebih baik pada perbaikan profil tegangan bus dan pengurangan rugi-rugi daya sistem Sulbagsel, dimana telah dibuktikan pada simulasi scenario 4 dan scenario 5, sehingga metode ACO adalah salah satu solusi untuk penentuan optimal lokasi dan besaran nilai daya reaktif kapasitor bank yang akan diterapkan pada sistem tenaga listrik.

\section{Ucapan Terima Kasih}

Ucapan terima kasih kepada Kementerian Riset Teknologi dan Pendidikan Tinggi Republik Indonesia atas bantuan dalam penyelesaian penelitian ini.

\section{Daftar Pustaka}

[1] M. Saini, R. Tandioga, A. Pangkung, dan A. M. S. Yunus, "Pengembangan Peralatan Simulasi Peralatan Aliran DayaBerbasis Fast Decoupled-Dependent NewtonRaphsondengan Program Interface-Based Delphi," Journal INTEK, April 2017, Vol. 4, No.1.

[2] Marwan, Nurhayati, A.S.A.A. Qahfi, dan R.A. Burhan, "Pengaruh Kapasitor Shunt Terhadap Susut Transmisi Sistem Interkoneksi Sulselbar BerbasisDIgSILENT Power Factory 15.1," Journal INTEK, April 2016, Vol. 3, No. 1.

[3] A.Fathurrahman, I.M.A. Nrartha, dan A.B. Muljono, "ESDM Ministry (Indonesia), 2016. PLN electric power supplybusiness plan for 2016 - 2025. Jakarta," Seminar Nasional 2012Teknik Elektro dan Informatika dalam Pengembangan Teknologi Berkelanjutan, Jurusan Teknik Elektro, UNRAM - Mataram, 17 Juli 2012.

[4] D.D. Yanuarta, S. Prasetyono, dan A. Saleh, "Rekonfigurasi Jaringan Distribusi Daya Listrik padaPenyulang Pakusari untuk Mengurangi Rugi-Rugi Daya dengan Metode Ant Colony Optimization (ACO), Berkala Sainstek 2015, Vol. III, No.1.

[5] F. Hia, Juningtyastuti, dan S. Handoko, "Optimasi Kapasitas DGpada Sistem Distribusi untukMengurangi Rugi Daya Menggunakan Ant Colony Optimization," Transient, Vol.4, No. 2, Juni 2015.

[6] J.D. Glover, dan M. Sarma, "Power System Analysis and Design," Second Edition, Boston : PWS Publishing Company, 1994.

[7] J.C. Das, "Power System Analysis : Short Circuit, Load Flow and Harmonic," Marcel Delder, 2002.

[8] H. Saadat, "Power System Analysis," McGraw-Hill, 1999.

[9] M. Dorigo and T. Stutzle, “Ant Colony Optimization,”The MIT Press, London, 2004.

[10] M.J. Kasaei, dan J.Nikoukar, " $D G$ Allocation with Consideration of Costs and Losses in Distribution Networks Using Ant Colony Algorithm," Majlesi Journal of Electrical Engineering, Vol. 10, No. 1, March 2016.

[11] D.N. Kummala, "Penentuan Letak Dan Kapasitas Kapasitor Menggunakan Ant Colony Optimization Untuk Pengurangan Rugi Daya Pada Sistem 150 kV Area Tapal Kuda," Skripsi, Jurusan Teknik Elektro, Universitas Jember, 2015.

[12] A. Zarman, M. Irfan, W. Uriawan, "Implementasi Algoritma Ant Colony Optimizationpada Aplikasi Pencarian Lokasi Tempat Ibadah Terdekat di Kota Bandung," JOIN, Vol. I, No. 1, Juni 2016. 